\title{
Pengkajian Evaluasi Pelatihan Vokasi Juru Sembelih Halal di Balai Besar Pelatihan Peternakan Batu Jawa Timur Tahun 2020
}

\author{
(Assessment Evaluation of Vocational Halal Slaughterer Training at International \\ Livestock Training Center Batu East Java Province 2020) \\ Kharisma Imam Adinata \\ Balai Besar Pelatihan Peternakan Batu \\ Penulis Korespondensi : Imamliya90@gmail.com
}

\begin{abstract}
ABSTRAK
Tujuan dari penelitian untuk mendeskripsikan hasil evaluasi penyelenggaraan pelatihan vokasi juru sembelih halal di Balai Besar Pelatihan Peternakan Batu dengan menggunakan metode deskriptif kualitatif. Pemilihan informan dilakukan dengan purposive sampling, yaitu teknik pengambilan sampel sumber data dengan pertimbangan tertentu. Data ditabulasi dari wawancara dengan narasumber sebagai informan. Analisa data dilakukan dengan mengklasifikasi dan mengambil hubungan antar data wawancara tersebut. Validitas data diuji dengan teknik triangulasi sumber data berdasarkan wawancara dengan narasumber sebagai informan. Dari hasil penelitian menunjukkan bahwa evaluasi pelatihan vokasi juru sembelih halal dapat dianalisa dengan empat aspek evaluasi yang saling terikat dan berpengaruh dari tahap reaksi peserta pelatihan menyatakan puas pada kondisi sarana dan prasarana Balai Besar Pelatihan Peternakan Batu dan widyaiswara yang menyampaikan materi selama penyelenggaraan pelatihan. Pada aspek pembelajaran peserta pelatihan mayoritas memahami materi pelatihan vokasi juru sembelih halal. Tahap kebiasaan peserta pelatihan mayoritas telah melaksanakan materi pelatihan yang disampaikan. Aspek hasil target peserta pelatihan telah mencapai target yang ditetapkan oleh Balai Besar Pelatihan Peternakan Batu yaitu dari peningkatan nilai pengetahuan, keterampilan, dan sikap.
\end{abstract}

Kata Kunci : Juru Sembelih Halal, Pelatihan, Evaluasi

\section{ABSTRACT}

The purpose of this research was to describe results evaluation of implementation halal slaughter vocational training at International Livestock Training Center Batu East Java using a qualitative descriptive method. The selection of informants was carried out by using purposive sampling technique. Data is tabulated from interviews with 
informants. Data analysis was carried out by classifying and taking the connection between the interview data. Validity of the data was tested by using triangulation technique data sources based on interviews with informants. The results show that the evaluation of halal slaughterer vocational training can be analyzed with four aspects of evaluation that are interrelated and influential from the reaction stage of the training participants who expressed satisfaction with conditions of facilities and infrastructure at International Livestock Training Center Batu East Java and trainer who delivered material during the training. In learning aspect, majority of the participants understand the vocational training material for halal slaughterers. Majority of trainees in the habitual stage have carried out the training material presented. Aspects of the results of the training participants' targets have reached the targets set by the Central for Stone Farming Training, namely from increasing the value of knowledge, skills, and attitudes.

\section{Keywords: Halal Slaughters, Training, Evaluation}

\section{PENDAHULUAN}

Indonesia adalah negara dengan mayoritas penduduk beragama islam, maka dari itu isu produk halal merupakan isu sensitif bagi masyarakat indonesia maka dari itu perlu adanya jaminan kehalalan khususnya produk dari hewan sembelihan yang dipotong seperti dari hewan ternak halal yaitu ternak ruminansia dan ternak monogastrik non babi.

Penyembelihan binatang yang akan digunakan sebagai bahan pangan yang halal harus dilakukan sesuai syariat islam yaitu sesuai dengan tuntunan yang dicontohkan oleh Rasulullah SAW yaitu memotong saluran nafas, makan, dan urat nadi pada leher hewan yang akan disembelih sesuai dengan syariat islam agar daging hewan yang dihasilkan aman, sehat, utuh, dan halal.

Sesuai syariat islam menyembelih hewan harus dilakukan dengan baik dan sesuai tuntunan sesuai sebagaimana sabda Rasulullah SAW : Segala sesuatu yang memancarkan darah dan disebut nama Allah padanya (ketika disembelih), maka makanlah. Tidak boleh (menggunakan pisau) dari gigi dan kuku.
Adapun gigi, itu adalah tulang. Adapun kuku, ia adalah pisau (alat menyembelih) orang Habasyah." (HR. al-Bukhari dan Muslim).

Penyembelihan hewan ternak dalam islam adalah ibadah yang diniatkan dengan menyebut asma Allah. Orang yang menyembelih hewan ternak dapat mengakibatkan daging hewan yang disembelihnya menjadi haram, sehingga daging hewan ternak yang disembelih tersebut tidak boleh dikonsumsi walaupun berasal dari hewan yang halal untuk dikonsumsi (Awaludin et al., 2017).

Pemerintah Melalui Kementerian Pertanian, Kementerian Ketenagakerjaan dan Majelis Ulama Indonesia hadir di masyarakat indonesia sebagai wujud komitmen untuk menyediakan bahan pangan yang ASUH (aman sehat utuh dan halal) melakukan pelatihan vokasi juru sembelih halal sesuai UU peternakan dan kesehatan hewan no 14 tahun 2014, SKKNI dan fatwa MUI nomor 12 tahun 2009.

Pelatihan adalah kegiatan yang dilaksanakan unit/organisasi dalam memberikan sebuah informasi dan pengetahuan kepada personal atau 
individu dalam menjalankan kegiatannya sehingga dapat mencapai target yang diinginkan (Hidayat dan Nurasyiah 2017). (Widiansyah, 2016) Menyatakan bahwa pelatihan adalah cara untuk memperoleh pembekalan pengetahuan dan keterampilan untuk meningkatkan profesionalitas dan kompetensi dalam melaksanakan pekerjaannya.

BBPP Batu adalah Unit Pelaksana Teknis (UPT) di bidang pelatihan yang berada di bawah dan bertanggung jawab kepada Kepala Badan Penyuluhan dan Pengembangan Sumber Daya Manusia Pertanian dan dibina oleh Kepala Pusat Pelatihan Pertanian. Balai Besar Pelatihan Peternakan Batu mempunyai tugas pokok : "Melaksanakan pelatihan fungsional bagi aparatur, pelatihan teknis dan profesi, mengembangkan model dan teknik pelatihan fungsional dan teknis di bidang peternakan bagi aparatur dan non aparatur pertanian".. BBPP Batu memiliki fungsi sebagai berikut : Penyusunan program, rencana kerja, anggaran dan pelaksanaan kerjasama; Pelaksanaan identifikasi kebutuhan pelatihan; Pelaksanaan penyusunan bahan standar kompetensi kerja (SKK) di bidang peternakan; Pelaksanaan pelatihan fungsional dibidang peternakan bagi aparatur; Pelaksanaan pelatihan teknis dibidang pasca panen dan pengolahan hasil ternak bagi aparatur dan non aparatur pertanian dalam dan luar negeri; Pelaksanaan pelatihan profesi dibidang pasca panen dan pengolahan hasil ternak bagi aparatur dan non aparatur; Pelaksanaan uji kompetensi di bidang peternakan; Pelaksanaan penyusunan paket pembelajaran dan media pelatihan fungsional dan teknis di bidang peternakan; Pelaksanaan pengembangan model dan teknik pelatihan fungsional dan teknis di bidang pasca panen dan pengolahan hasil ternak; Pelaksanaan pengembangan kelembagaan pelatihan peternakan swadaya; Pelaksanaan pemberian konsultasi di bidang peternakan; Pelaksanaan bimbingan lanjutan pelatihan dibidang peternakan bagi aparatur dan non aparatur; Pelaksanaan pemberian pelayanan penyelenggaraan pelatihan fungsional bagi aparatur, pelatihan teknis dan profesi, pengembangan model dan teknik pelatihan fungsional dan teknis di bidang peternakan bagi aparatur dan non aparatur pertanian; n. Pengelolaan unit inkubator usaha tani; Pelaksanaan pemantauan dan evaluasi dibidang pelatihan peternakan; Pelaksanaan pengelolaan data dan informasi pelatihan serta pelaporan; Pelaksanaan pengelolaan sarana teknis; Pengelolaan urusan kepegawaian, keuangan, rumah tangga, perlengkapan dan instalasi BBPP Batu.

Balai Besar Pelatihan Peternakan Batu sebagai unit pelaksana vertikal Kementerian Pertanian memiliki tugas pelayanan pelatihan yang terdiri dari 2 jenis pelatihan yaitu pelatihan teknis dan pelatihan fungsional dan tiap-tiap jenis pelatihan diatas memiliki tujuan untuk meningkatkan kompetensi dan kinerja aparatur sipil negara dan non aparatur sipil negara.

Pelatihan vokasi juru sembelih halal diikuti oleh peserta pelatihan dari unsur non aparatur sipil negara, dimana pelatihan yang dilaksanakan guna memberi kompetensi dinidang teknis juru sembelih halal sehingga diharapkan peserta pelatihan setelah mengikuti pelatihan mampu mengaplikasikan kompetensi dibidang penyembelihan halal dapat dilaksanakan sesuai syariat islam dan dilaksanakan dengan sebaikbaiknya.

Metode pelatihan yang diajarkan menggunakan metode pembelajaran orang dewasa (POD)/andragogy. Materi pelatihan vokasi juru sembelih halal 
disusun oleh widyaiswara yang kompeten dibidang juru sembelih halal, dan pelaksanaan pelatihan dilakukan oleh Balai Besar Pelatihan Peternakan Batu Jawa Timur. Pelatihan Vokasi Juru Sembelih halal diselenggarakan dalam dua angkatan pada bulan februari 2020 dimulai tanggal 4 februari 2020 dan diakhiri pada tanggal 17 februari 2020.

Penelitian ini bertujuan untuk mengetahui efektivitas pelatihan vokasi juru sembelih halal yang dilakukan oleh balai besar pelatihan peternakan batu sehingga diharapkan dapat diaplikasikan peserta pelatihan di masyarakat guna tercapainya produk pangan yang ASUH (aman, sehat, utuh, halal) dan sesuai syariat islam.

Permasalahan yang akan diselesaikan dalam penelitian ini adalah bagaimana hasil dari pelatihan vokasi juru sembelih halal tahun 2020 yang diselenggarakan oleh balai besar pelatihan peternakan batu?

Tujuan dari penelitian ini untuk mengevaluasi pelaksanaan pelatihan vokasi juru sembelih halal yang diselenggarakan di balai besar pelatihan peternakan batu, sehingga dapat memberikan informasi yang dapat digunakan dalam pengembangan sumber daya manusia pertanian serta sebagai acuan untuk penelitian sejenis.

\section{METODE PENELITIAN}

Metode yang digunakan dalam pengkajian ini adalah dengan penelitian kualitatif yaitu memerlukan data berupa informasi secara deskriptif (Subandi, 2011). Wahidmurni (2016) menjelaskan bahwa penelitian kualitatif adalah suatu metode penelitian yang berlandaskan pada nilai positivisme, dipergunakan untuk mengkaji kondisi objek fenomena yang alamiah dimana peneliti bertindak sebagai instrumen utama, maka harus mempunyai dasar teori kuat dan wawasan yang luas, pengambilan sampel sumber data dilakukan secara purposive (sengaja) analisis data bersifat kualitatif dan apa adanya.

Pemilihan lokasi penelitian dilakukan di Balai Besar Pelatihan Peternakan Batu dikarenakan pertimbangan balai besar pelatihan peternakan batu merupakan unit pelaksana teknis vertikal Kementerian Pertanian yang fokus meningkatkan kemampuan dan keterampilan sumber daya manusia tentang peternakan, produk, dan hasil sampingnya melalui pelatihan. BBPP Batu diberi mandat sebagai penyelenggara pelatihan vokasi juru sembelih halal dengan sampel yang diperoleh dari peserta pelatihan yaitu peserta yang mengikuti pelatihan vokasi juru sembelih halal di BBPP Batu. Teknik pengumpulan data yang digunakan dengan cara observasi, wawancara, dan instrumen monitoring dan evaluasi. Teknik penentuan informan menggunakan cara purposive sampling yaitu memilih informan, informan yang dipilih adalah pihak yang memahami problema serta mampu memberikan informasi yang lengkap. Model verifikasi data dengan triangulasi sumber data yaitu pengecekan kesahihan data dengan memanfaatkan sumber informasi sebagai pembanding. Analisis data dengan menggunakan reduksi data, penyajian data, dan kesimpulan.

\section{HASIL DAN PEMBAHASAN}

Proses evaluasi secara
obyektif dan sistematis
dibutuhkan dalam penyelenggaraan
pelatihan. Pengkajian riset ini
menggunakan metode evaluasi
kirkpatrick yang membagi kedalam
empat penggolongan dengan alur
monitoring dan evaluasi dari


penyelenggaraan pelatihan. Tahapannya antara lain : 1) Reaksi yaitu pandangan, pendapat dari peserta pelatihan mengenai fasilitas kelengkapan infrastruktur tempat pelatihan, materi yang disampaikan, widyaiswara dalam pelaksanaan pelatihan. (2) Tahap pembelajaran yaitu mengukur tingkat pemahaman materi peserta yang disampaikan oleh widyaiswara. (3) Tahapan Perilaku yaitu mengukur perubahan perilaku setelah mengikuti pelatihan dan mengaplikasikannya di lingkungan asal peserta (4) Tahap Hasil yaitu mengukur efektivitas pelaksanaan pelatihan dalam merubah sikap, keterampilan, dan pengetahuan peserta pelatihan.

\subsection{Tahapan Reaction (Reaksi)}

Tahapan reaksi seperti yang dijelaskan Kirkpatrick adalah reaksi dari peserta dalam menanggapi pelatihan yang diikuti. Reaksi peserta pelatihan berupa pandangan, kemauan, pendapat terhadap pelaksanaan pelatihan vokasi juru sembelih halal. Peserta pelatihan akan merasa puas terhadap penyelenggaraan pelatihan maka mereka akan berubah baik itu dalam hal sikap, pengetahuan, maupun perilaku dan akan berusaha mengaplikasikan ilmu yang didapat dalam pelatihan kedalam lingkungan asal masing-masing peserta.

Pengkajian ini, tahapan reaksi yang ingin diteliti meliputi sarana dan prasarana pelatihan yang disediakan, evaluasi widyaiswara terhadap penguasaan materi dan metode penyampaian teknis, dan sarana dan prasarana yang perlu diperbaiki menjadi lebih baik. Instrumen penilaian diatas digunakan untuk mengetahui tingkat kepuasan peserta pelatihan selama mengikuti pelatihan, Pelaksanaan pelatihan dinilai efektif apabila mayoritas peserta menilai puas/baik
Aspek kesediaan sarana dan prasarana yang memadai yang ada di Balai Besar Pelatihan Peternakan Batu dari penilaian peserta menyatakan sudah baik/puas. Sarana dan Prasarana yang perlu ditingkatkan oleh 1 dari 4 informan memberikan tanggapan guna meningkatkan akses sinyal jaringan internet/wifi.

Aspek penilaian widyaiswara terhadap penguasaan materi dan metode penyampaian, mayoritas peserta pelatihan menilai sangat baik, 3 dari 4 informan menyatakan metode instrumen penilaian widyaiswara tersebut membantu dalam menyerap aspirasi dari peserta pelatihan, dan dari informan menyatakan bahwa penguasaan materi dan metode penyampaian widyaiswara sudah kompeten dan kapabel dibidangnya. Kelebihan dan kekurangan widyaiswara/fasilitator dari pernyataan informan bahwa kelebihan widyaiswara dan fasilitator pada metode penyampaian materi sudah baik dan interaktif sedangkan kekuranganya adalah penilaian informan 1 dari 4 orang menyatakan bahwa materi dari fasilitator kurang jelas dan minim kegiatan praktek.

Berdasar pengkajian diatas terhadap reaksi peserta pelatihan pasca mengikuti pelatihan vokasi juru sembelih halal menyatakan bahwa reaksi peserta pelatihan mulai dari sarana dan prasarana pelatihan yang disediakan, evaluasi widyaiswara terhadap penguasaan materi dan metode penyampaian teknis, dan sarana dan prasarana yang perlu diperbaiki mayoritas menilai puas, dan keinginan peserta pelatihan pada penyelenggaraan pelatihan berikutnya agar pihak BBPP batu meningkatkan akses sinyal jaringan wifi agar peserta pelatihan merasa nyaman dan puas sehingga tujuannya kelak agar memotivasi peserta dan sarana promosi kepada khalayak umum 
tentang pelatihan yang diselenggarakan BBPP batu, dimana pelatihan vokasi juru sembelih halal dilaksanakan untuk meningkatkan sikap keterampilan dan pengetahuan tentang penyembelihan hewan ternak sesuai syariat islam sehingga mewujudkan produk pangan yang ASUH (aman sehat utuh halal).

\subsection{Tahap Learning (Pembelajaran)}

Pembelajaran pelatihan adalah mengetahui keterampilan, pengetahuan, dan sikap pada peserta selama dalam pelatihan (Kirkpatrick, 1994). Widyaiswara memiliki tugas dan fungsi melakukan pendidikan mengajar dan melatih guna meningkatkan sikap, pengetahuan dan keterampilan. Indikator keberhasilan pelatihan vokasi juru sembelih halal ini apabila peserta mengalami peningkatan pengetahuan, keterampilan, maupun sikap. Evaluasi yang digunakan antara lain pemahiran dan evaluasi pre dan post test. Evaluasi sangat penting dilakukan agar peserta dapat mengerti dengan baik materi yang telah disampaikan oleh widyaiswara/fasilitator.

Tahap learning (pembelajaran) telah peneliti tentukan berdasarkan materi inti sesuai kurikulum pelatihan vokasi juru sembelih halal yang disampaikan oleh widyaiswara/fasilitator yaitu: menerapkan persyaratan juru sembelih halal, menerapkan higiene sanitasi, menerapkan prinsip kesejahteraan hewan, menyiapkan peralatan penyembelihan, melakukan pemeriksaan fisik hewan dan penyembelihan halal. Poin materi diatas digunakan untuk mengetahui pemahaman peserta terhadap materi yang disampaikan selama proses pelatihan vokasi juru sembelih halal berlangsung. Peserta pelatihan mayoritas memahami materi yang telah disampaikan diatas tadi maka dapat diambil kesimpulan pelatihan tercapai keberhasilan.

Materi menerapkan persyaratan juru sembelih halal semua informan dari 4 informan menyatakan mampu menyebutkan 4 kriterianya yaitu mendirikan sholat, menerapkan syarat dan rukun penyembelihan halal, kode etik penyembelihan halal, menetapkan status kematian hewan.

Materi menerapkan higiene sanitasi 1 informan menyatakan mampu menyebutkan 5 kriteria yaitu : menerapkan higiene personal, kondisi sehat, menggunakan alat pelindung diri, mencuci tangan dengan sabun, tidak melakukan tindakan yang dapat mengkontaminasi produk, 2 informan hanya dapat menjelaskan 3 kriteria yaitu kondisi sehat, menggunakan alat pelindung diri, mencuci tangan, 1 informan hanya dapat menjelaskan 1 kriteria yaitu menggunakan alat pelindung diri.

Materi menerapkan prinsip kesejahteraan hewan 2 informan menyatakan menerapkan 5 kriteria yaitu menerapakan prinsip kesejahteraan hewan, mengidentifikasi kondisi fisik dan perilaku hewan, melakukan tatacara pemeriksaan hewan sesuai prinsip kesejahteraan hewan, mengidentifikasi kondisi sarana dan prasarana yang layak untuk penyembelihan, memeriksa kesesuaian tata lingkungan sesuai dengan jenis hewan. 2 informan lainnya hanya bisa menjelaskan 3 tata cara prinsip kesejahteraan hewan yaitu mengidentifikasi kondisi fisik dan perilaku hewan, melakukan tatacara pemeriksaan hewan sesuai prinsip kesejahteraan hewan, menerapkan prisnsip kesejahteraan hewan

Materi Menyiapkan peralatan penyembelihan dari 4 informan menyatakan mampu menjelaskan 4 kriteria yaitu : memilih pisau sesuai 
peruntukannya, mengasah pisau dan menguji ketajamannya, membersihakan pisau sesuai hygiene sanitasi, menyimpan pisau sesuai ketentuan.

Materi melakukan pemeriksaan fisik hewan dari 4 informan kesemuanya hanya dapat menjelaskan 3 kriteria dari 4 persyaratan materi yaitu : memastikan hewan masih hidup, memastikan hewan yang akan disembelih dalam kondisi sehat, memastikan hewan tidak menderita penyakit menular.

Materi penyembelihan halal dari 4 informan kesemuanya menyatakan memahami 7 kriteria melakukan penyembelihan halal yaitu : menetapkan posisi hewan, menetapkan sayatan penyembelihan, membaca basmalah, menggunakan pisau penyembelihan, memeriksa penampang sayatan dan proses pengeluaran darah, memeriksa tanda-tanda kematian hewan.

Berdasar pengkajian yang telah dilakukan, bahwa peserta pelatihan vokasi juru sembelih halal memahami seluruh pembelajaran yang disampaikan widyaiswara/fasilitator khususnya tentang materi inti pelatihan yang diajarkan pada pelatihan vokasi juru sembelih halal, yaitu tentang menerapkan persyaratan juru sembelih halal, menerapkan higiene sanitasi, menerapkan prinsip kesejahteraan hewan, menyiapkan peralatan penyembelihan, melakukan pemeriksaan fisik hewan dan melakukan penyembelihan halal. Peserta pelatihan vokasi juru sembelih halal memperoleh peningkatan pengetahuan, keterampilan, dan sikap dari pelatihan yang diadakan balai besar pelatihan peternakan batu tahun 2020. Dengan pembuktian peserta pelatihan mampu menjelaskan materi yang telah diajarkan selama pelatihan berlangsung. Pengakajian ini selaras dengan hasil pre dan post test pada angkatan pertama dan kedua masing- masing nilai pretest terendah sebesar 20 dan 24 dan setelah post test tertinggi masing-masing sebesar 100 dan 100 dengan rata - rata presentase kemajuan berlatih angkatan pertama dan kedua masing-masing sebesar 97,86 dan 92,77.

\subsection{Tahap Behavior (Kebiasaan)}

Aspek perilaku adalah penerapan materi yang didapat peserta selama pelatihan dilingkungan kerja masingmasing. Fokus perilaku ini pada keterampilan peserta pelatihan dalam menerapkan ilmu di daerahnya masingmasing. Indikator keberhasilan pada aspek perilaku ini juga dipengaruhi oleh faktor reaksi dan pembelajaran sebelumnya. Faktor reaksi dan pembelajaran dari peserta sudah baik maka penerapan materi pelatihan di lingkungan kerja masin-masing akan baik juga. Pelatihan pada peserta vokasi juru sembelih halal bertujuan pada peningkatan pengetahuan, keterampilan, dan sikap.

Pengkajian tahap perilaku yang peneliti tentukan mencakup materi inti sesuai kurikulum pelatihan vokasi juru sembelih halal yaitu : menerapkan persyaratan juru sembelih halal, menerapkan higiene sanitasi, menerapkan prinsip kesejahteraan hewan, menyiapkan peralatan penyembelihan, melakukan pemeriksaan fisik hewan, dan melakukan penyembelihan halal.

Pada aspek menerapkan persyaratan juru sembelih halal semua informan dari 4 orang informan menyatakan sudah menerapkan dilingkungan kerjanya didaerahnya masing-masing. Materi higiene sanitasi dari 4 informan yang diwawancarai 3 orang menerapkan dengan lengkap 5 kriteria syarat higiene sanitasi dan 1 orang hanya melaksanakan 3 dari 5 syarat higiene sanitasi dengan hasil 
barang bukti berupa buku pencatatan dan foto kegiatan. Pada Materi prinsip kesejahteraan hewan dari 4 informan hanya melaksanakan 4 kriteria dari 5 kriteria menerapkan prinsip kesejahteraan hewan dengan barang bukti yang dilampirkan berupa foto kegiatan dan buku pencatatan.

Materi menyiapkan peralatan penyembelihan seluruh informan dari 4 orang informan menyatakan sudah menerapkan 4 kriteria di lingkungan kerja di daerah masing-masing dengan melampirkan barang bukti berupa foto kegiatan dan buku pencatatan. Materi melakukan pemeriksaan fisik hewan dari 4 informan sudah melaksanakan 4 kriteria sesuai standar melakukan pemeriksaan fisik hewan didaerah masing masing dengan barang bukti berupa foto kegiatan. Materi melakukan penyembelihan halal 4 orang informan menyatakan sudah melaksanakan 7 kriteria yang dipersyaratkan dalam hal melakukan penyembelihan halal pada hewan dengan melampirkan foto kegiatan dan buku pencatatan penyembelihan.

Materi-materi yang telah dikumpulkan dari para informan diatas kemudian ditabulasi dan dianalisa, kemudian diambil sebuah kesimpulan bahwa peserta pelatihan vokasi juru sembelih halal mayoritas menerapkan materi yang telah diajarkan oleh widyaiswara di BBPP Batu. Peserta pelatihan terbukti melakukan penerapan di lingkungan kerja didaerahnya masingmasing dibuktikan dengan lampiran barang bukti berupa foto kegiatan dan buku pencatatan.

\subsection{Tahap Result (Hasil)}

Tahap hasil seperti yang dijelaskan oleh Kirkpatrick adalah output akhir setelah peserta mengikuti pelatihan vokasi juru sembelih halal dengan adanya peningkatan kinerja individu maupun organisasi secara keseluruhan berdasarkan pengetahuan, keterampilan, dan sikap dari peserta pelatihan.

Pengkajian ini, tahap hasil yang ditentukan oleh pengkaji mencakup pentingnya dilakukan pelatihan, hasil akhir yang ingin dicapai, hasil yang telah dicapai, dan hambatan dalam mencapai hasil akhir.

Tahapan penting dilakukan pelatihan vokasi juru sembelih halal adalah amanat Undang-undang nomor 33 tahun 2014 tentang jaminan produk halal dimana ada standarisasi yang harus dipenuhi agar sebuah produk dikategorikan sebagai produk halal dan memberikan kepastian dan jaminan hukum kepada masyarakat muslim dari produk yang beredar di Indonesia, dan sesuai Undang-undang peternakan dan kesehatan hewan no 41 tahun 2014 dimana salah satu poin dalam undangundang tersebut tersedianya produk pangan hewani dari ternak harus mensyarat wajibkan ASUH (aman, sehat, utuh, halal) dimana praktek penyembelihan ternak secara syari masih belum terstandarisasi di masyarakat indonesia secara umum.

Tahap hasil akhir yang ingin dicapai dengan diselenggarakannya pelatihan vokasi juru sembelih halal adalah agar peserta pelatihan vokasi juru sembelih halal dalam aspek pengetahuan, ketermapilan, sikap dan standarisasi dapat meningkat dalam pelaksanaan penyembelihan ternak baik sebelum maupun sesudah penyembelihan sampai dengan pendistribusian sebagai produk pangan yang ASUH (aman, sehat,utuh, halal).

Hasil yang telah dicapai setelah penyelenggaraan pelatihan vokasi juru sembelih halal yaitu peserta pelatihan sudah menerapkannya di wilayah kerja masing-masing dan meningkatnya 
kompetensi peserta pelatihan dalam aspek penyembelihan halal dan sesuai standar. Tidak keseluruhan target tercapai karena belum semua tenaga teknis pelaksana penyembelihan secara halal memperoleh pelatihan.

Hambatan dalam mencapai hasil akhir berbeda karena sistem pengawasan pemerintah dalam hal ini kementerian pertanian lewat dinas pertanian/peternakan masih terbatas dalam mengawal kinerja purnawidya pasca pelatihan.

Dari pengkajian aspek hasil diatas diperoleh bahwa peserta setelah mengikuti pelatihan vokasi juru sembelih halal, peserta sudah menerapkan di daerah asal masing-masing sehingga alumni pelatihan tersebut diharapkan dapat menjamin kehalalan produk khususnya daging.

\section{KESIMPULAN}

Monitoring dan evaluasi pelatihan harus dilakukan oleh organisasi yang memiliki kewenangan menyelenggarakan pelatihan guna mengetahui ada tidaknya peningkatan pengetahuan, keterampilan, sikap dari peserta pelatihan guna menarik sebuah kesimpulan perbaikan-perbaikan pelaksanaan pelatihan dimasa mendatang. Dilihat dari monitoring dan evaluasi dengan menggunakan metode dari Kirkpatrick yang membagi kedalam 4 (empat) aspek, dapat diambil sebuah kesimpulan yaitu :

1. Tahap Reaksi: tahapan ini peserta pelatihan memberi masukan dan tanggapan mengenai kesediaan sarana dan prasarana yang memadai yang ada di Balai Besar Pelatihan Peternakan Batu dari penilaian peserta menyatakan sudah baik/puas. Kompetensi widyaiswara/fasilitator berdasarkan pendapat peserta sudah baik dan interaktif. Fasilitas yang perlu diperbaiki adalah peningkatan jaringan internet/wifi.

2. Tahap Pembelajaran : aspek ini tingkat pembelajaran peserta pelatihan dinilai dari diseminasi pengetahuan, keterampilan, sikap dalam pelatihan vokasi juru sembelih halal. Peserta pelatihan mayoritas memahami materi yang telah disampaikan oleh widyaiswara dalam pelatihan ini. Materi yang telah disampaikan oleh widyaiswara meliputi menerapkan persyaratan juru sembelih halal, menerapkan higiene sanitasi, menerapkan prinsip kesejahteraan hewan, menyiapkan peralatan penyembelihan, melakukan pemeriksaan fisik hewan dan penyembelihan halal.

3. Tahap kebiasaan : aspek ini untuk mengetahui penerapan hasil pelatihan peserta pelatihan di tempat kerja di wilayahnya masing-masing. Peserta pelatihan mayoritas menerapkan materi pelatihan yang telah disampaikan dalam pelatihan vokasi juru sembelih halal di wilayah kerjanya dan diketahui dari pernyataan dan dokumen barang bukti yang dilampirkan oleh peserta pelatihan.

4. Tahap hasil : aspek ini menilai target yang telah ditetapkan oleh Balai Besar Pelatihan Peternakan Batu. Indikator keberhasilan target yang telah tercapai adalah peserta pelatihan vokasi juru sembelih halal sudah meningkat dalam hal pengetahuan, keterampilan, dan sikap dan mayoritas menerapkan di wilayah kerjanya masing-masing dalam hal melakukan penyembelihan halal.

\section{DAFTAR PUSTAKA}


Awaludin, A., Y. R. Nugraheni, dan S. Nusantoro. 2017. Teknik Handling dan Penyembelihan Hewan Bbppbatu.bppsdmp.pertanian.go.id

Fatwa MUI nomor 12 tahun 2009. Tentang Sertifikasi Penyembelihan Halal.

Hidayat dan Nurasyiah, 2017. Pengaruh Diklat (Pendidikan dan Pelatihan) Terhadap Prestasi Kerja Karyawan di Bank BPR Rokan Hulu. Jurnal Ilmiah Cano Ekonomos. 6(1):71-82.

Kirkpatrick, Donald L. 1994. Evaluating Training Programs: The Four Levels. Berrett-Koehler. San Fransisco.

Subandi. 2011. Deskripsi Kualitatif Sebagai Satu Metode Dalam Penelitian Pertunjukan. Jurnal Harmonia. 11(2): 173-179.

Undang-undang nomor 33 tahun 2014. Tentang Jaminan Produk Halal.

Undang-undang nomor 41 tahun 2014. Tentang Peternakan dan Kesehatan Hewan.

Wahidmurni. 2016. Pengembangan Usaha Bisnis: Studi Pengalaman Pengusaha Muda Sukses. Laporan Penelitian, Tidak diterbitkan. Malang : Fakultas Ilmu Tarbiyah dan Keguruan UIN Malana Malik Ibrahim. Malang

Widiansyah, H. 2016. Studi Deskriptif tentang Evaluasi Tahapan Teknis Kepala Desa oleh Badan Diklat Provinsi Jawa Timur Tahun 2014. Jurnal Kebijakan dan Manajemen Publik. 4(2): 126-134.
Qurban. Jurnal Pengabdian Masyarakat Peternakan 2(2):84-97. 